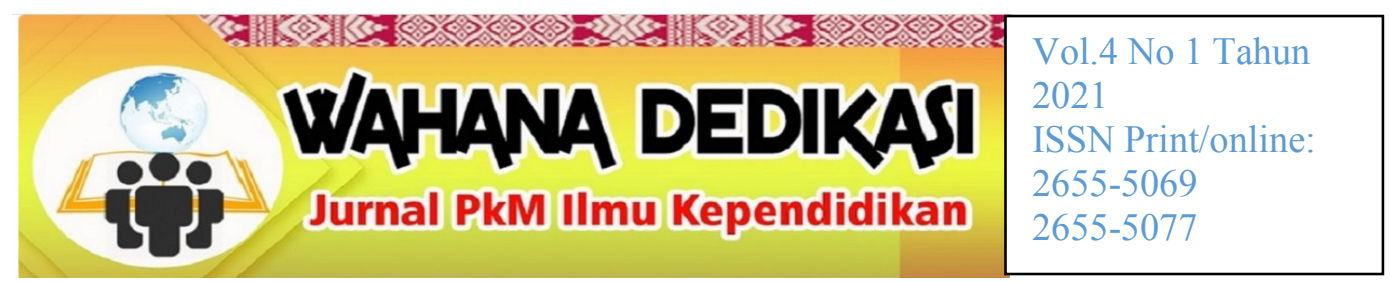

\title{
Manajemen aktualisasi diri selama masa New normal di sma dek kota padang
}

\author{
Helma $^{1}$, Fuadillah Putra ${ }^{2}$, Yasrial Chandra ${ }^{3}$ \\ ${ }^{1,2,3}$ STKIP PGRI Sumatera Barat \\ helmajama10227@gmail.computraalyanifahmi@gmail.com², chandrayasrial@gmail.com³
}

\begin{abstract}
Abstrak
Manajemen kecerdasan dan aktualisasi diri merupakan suatu kompetensi yang leh seorang individu dalam menghadapi masa pandemic seperti saat sekarang ini, baik baik seorang peserta didik, pendidik, pekerja kantoran dan lainnya.Hal ini dikarenakan dengan adanya kekampuan dalam mengatur diri sehingga dimasa pandemic ini seorang individu masih data berkarya denga berbagai maam protocol Kesehatan yang ketat. Dengan ulasan dan analisis situasi tentang pentingnya pemahaman atau sutdi interaktif tentang Manajemen kecerdasan dan aktualisasi diri dimasa new normal oleh peserta didik penting diberikan, sehingga tujuan dari Pendidikan yaitu mengembangkan potensi peserta didik agar menjadi manusia yang beriman dan bertakwa kepada Tuhan Yang Maha Esa, berakhlak mulia, sehat, berilmu, cakap, kreatif, mandiri, dan menjadi warga negara yang baik dapat terwujud
\end{abstract}

Kata kunci: Aktualisasi Diri, New Normal, Siswa

Artikel disetujui tanggal: 30-05-2021

Corresponden Author:Yasrial Chandra e-mail:chandrayasrial@gmail.com

DOI: http://dx.doi.org/10.31851/dedikasi.v4i1.5321 do

PENDAHULUAN

Jika kualitas pendidikan diharapkan tercapai secara optimal, perlu diupayakan bagaimana membina peserta didik untuk memiliki kecerdasan emosi yang stabil sebagai penyeimbang dari inteligensi yang ada (Perbowosari, 2016). Sebab, melalui kecerdasan emosional peserta didik dapat memahami diri dan lingkungannya secara tepat, memiliki rasa percaya diri, tidak mudah putus asa, dan dapat membentuk karakter peserta didik secara positif. Pendidikan adalah suatu usaha yang sadar dan sistematis dalam mengembangkan potensi peserta didik.

Budaya adalah keseluruhan sistem berpikir, nilai, moral, norma, dan keyakinan (belief) manusia yang dihasilkan masyarakat. Sedangkan 


\section{W/AHANA DEDIKASI}

karakter adalah watak, tabiat, akhlak, atau kepribadian seseorang yang terbentuk dari hasil internalisasi berbagai kebajikan (virtues) yang diyakini dan digunakan sebagai landasan untuk cara pandang, berpikir, dan bersikap Jadi pendidikan budaya dan karakter adalah suatu usaha sadar dan sistematis dalam mengembangkan potensi peserta didik agar mampu melakukan proses internalisasi, menghayati nilai-nilai menjadi kepribadian mereka dalam bergaul di masyarakat, dan mengembangkan kehidupan masyarakat yang lebih sejahtera,serta mengembangkan kehidupan bangsa yang bermartabat.

Triatna (2011) menyatakan, pendidikan karakter adalah pendidikan emosi atau pendidikan budi pekerti plus, yaitu pendidikan yang melibatkan aspek pengetahuan (cognitive), perasaan (feeling), dan tindakan (action). Tanpa ketiga aspek ini, maka pendidikan karakter tidak akan efektif, dan pelaksanaannya pun harus dilakukan secara sistematis dan berkelanjutan. Dengan pendidikan karakter, emosi peserta didik akan menjadi cerdas. Kecerdasan emosi adalah bekal terpenting dalam mempersiapkan peserta didik menyongsong masa depan yang penuh dengan tantangan.

Bisa menjadi penegasan bahwa tujuan pendidikan, budaya dan karakter bangsa (Oktarosada, 2017) adalah: 1). mengembangkan potensi kalbu/nurani/afektif peserta didik sebagai manusia dan warganegara yang memiliki nilai-nilai budaya serta karakter bangsa; 2). mengembangkan kebiasaan dan perilaku peserta didik yang terpuji dan sejalan dengan nilainilai universal dan tradisi budaya bangsa yang religius; 3). menanamkan jiwa kepemimpinan dan tanggung jawab peserta didik sebagai generasi penerus bangsa; 4). mengembangkan kemampuan peserta didik menjadi manusia yang mandiri, kreatif, berwawasan kebangsaan; dan 5). mengembangkan lingkungan kehidupan sekolah sebagai lingkungan belajar yang aman, jujur, 


\section{WAHANA DEDIKASI}

penuh kreativitas dan persahabatan, pertumbuhan jika dan hanya jika serta dengan rasa kebangsaan yang tinggi dan penuh kekuatan (dignity).

Nilai-nilai yang

dikembangkan dalam pendidikan budaya dan karakter bangsa adalah: 1). Religius; 2). Jujur; 3). Toleransi 4). Disiplin; 5). Kerja keras 6). Kreatif; 7). Mandiri; 8). Demokratis; 9).Rasa ingin tahu; 10). Semangat kebangsaan; 11). Cinta tanah air; 12). Menghargai prestasi;

13). Bersahabat/Komuniktif; 14).Cinta damai; 15).Gemar membaca; 16).Peduli lingkungan; 17).Peduli sosial; dan 18). Tanggung-jawab.

McLeod, (2007) Maslow Hierarchy of Needs menggunakan istilah aktualisasi diri (self actualization) sebagai kebutuhan dan pencapaian tertinggi seorang manusia. Arianto (2009) menjelaskan aktualisasi diri adalah proses menjadi diri sendiri dan mengembangkan sifat-sifat dan potensi psikologis yang unik. Menurut Herts, Wallis, E., \& Maslow. (2014) seorang individu siap untuk bertindak sesuai kebutuhan kebutuhan kekurangan terpenuhi, konseptualisasi awal Maslow hanya mencakup satu kebutuhan pertumbuhan -aktualisasi diri.

\section{Orang-orang}

yang teraktualisasi diri dicirikan oleh: 1) fokus pada masalah; menggabungkan kesegaran apresiasi hidup yang terus berlanjut; 3) keprihatinan tentang pertumbuhan pribadi; dan 4) kemampuan untuk memiliki pengalaman puncak. Tanpa memandang suku asal-usul seseorang, setiap manusia mengalami tahaptahap peningkatan kebutuhan atau pencapaian dalam kehidupannya.

Kebutuhan tersebut meliputi kebutuhan fisiologis, kebutuhan keamanan dan keselamatan, kebutuhan sosial, kebutuhan akan penghargan, dan kebutuhan aktualisasi diri. Aktualisasi diri merupakan penggunaan dan pemanfaatan secara penuh bakat, kapasitas-kapasitas, potensi-potensi yang dimiliki oleh manusia untuk memenuhi kebutuhan diri tersebut. 


\section{WAHANA DEDIKASI \\ Proses aktualisasi adalah}

Terhubung

dengan

perkembangan atau penemuan jati diri dan berkembang suatu potensi yang dimiliki oleh manusia.

Organisme manusia mencaku semua pengalaman yang tersedia pada saat tertentu, baik sadar maupun tidak sadar (Susanto, \& Akmal., 2018). Seiring perkembangan sebagian bidang ini menjadi berbeda dan ini menjadi "diri" seseorang, diri adalah konstruksi sentral, ini berkembang melalui interaksi dengan orang lain dan melibatkan kesadaran akan keberadaan dan fungsi. Bentuk psikologis yang jelas dari kecenderungan aktual yang terkait dengan diri ini adalah kecenderungan aktualisasi diri, ini melibatkan aktualisasi dari bagian pengalaman yang dilambangkan dalam diri (Syaharuddin, Rahman, \& Fitriyani., 2020). Hal ini dapat dilihat sebagai dorongan untuk mengalami diri sendiri dengan cara yang konsisten dengan pandangan seseorang tentang beberapa hal (Goble, 1994).

pengembangan konsep diri dan aktualisasi diri adalah kebutuhan sekunder (diasumsikan kemungkinan dapat dipelajari di masa kanakkanak): kebutuhan untuk hal positif dari orang lain dan kebutuhan akan penghargaan diri yang positif, hal ini mengarah pada mendukungnya suatu perilaku yang konsisten dengan konsep diri seseorang. Manusia yang beraktualisasi dimotivasi oleh metakebutuhan yang berorientasi pada penyesuaian kehidupan individu dengan kecenderungankecenderungan aktualisasi diri yang unik dan ditujukan untuk meningkatkan pengalaman yang mengarah pada pertumbuhan dalam diri, kreativitas adalah kualitas menonjol di aktualisasi diri, bahwa orang-orang yang mengaktualisasikan diri dan kebutuhan yang digambarkan pada hierarki piramidal nya deskriptif, sebagai lawan secara eksplisit. New normal adalah perubahan perilaku atau kebiasaan untuk tetap menjalankan aktivitas 


\section{WAHANA DEDIKASI}

seperti biasa namun dengan selalu menerapkan protokol kesehatan di tengah pandemi COVID-19.

Himbauan dari pemerintah ini menganjurkan agar kita bisa hidup "berdampingan" dengan virus yang telah menelan ratusan ribu jiwa di seluruh dunia. Sejak pandemi COVID-19 muncul, hampir semua orang mengalami kendala untuk menjalani kehidupan normal akibat pembatasan yang perlu dilakukan untuk mencegah penularan virus Corona. Namun, dengan usainya pembatasan tersebut, pemerintah menganjurkan kita untuk mulai melakukan kegiatan seperti biasa, tentunya sambil mematuhi protokol pencegahan COVID-19.

Hal ini mendorong kita untuk lebih gencar dalam menerapkan langkah pencegahan dasar COVID19, seperti mencuci tangan dengan sabun dan air mengalir atau dengan hand sanitizer, tidak menyentuh wajah dengan tangan yang belum dicuci, menerapkan physical distancing, serta mengenakan masker dalam setiap aktivitas, terutama di tempat umum. Berikut adalah hal-hal penting yang perlu kamu ketahui untuk menghadapi new normal:

1.Saat harus keluar rumah dan kembali lagi ke rumah

2.Penerapan new normal akan membuat kita lebih longgar untuk keluar rumah. Namun, mengingat pandemi COVID-19 masih berlangsung, kita harus tetap menerapkan langkah pencegahan dasar kapan pun dan di mana pun kita berada.

3.Sewaktu menggunakan transportasi umum.

Bila kamu harus bepergian ke suatu tempat dan menggunakan transportasi umum, ada beberapa hal yang perlu diperhatikan selain menerapkan langkah pencegahan dasar.Untuk memudahkanmu dalam menjaga kebersihan tangan, bawalah selalu hand sanitizer.

Jangan menyentuh wajah dengan tangan yang belum dibersihkan (Syaharuddin, 2020). 


\section{WAHANA DEDIKASI}

Selain itu, pastikan kamu membawa botol minum agar tetap terhidrasi selama perjalanan. Yang paling penting untuk diingat selama berada di dalam transportasi umum adalah mengurangi interaksi dan menjaga jarak setidaknya 1 meter dengan penumpang lain. Bila hal ini tidak memungkinkan, sebaiknya jangan menggunakan transportasi umum.

Wajib Menggunakan Masker

Setiap sekolah yang sudah membuka proses pembelajaran di sekolah wajib mempersiapkan sarana cuci tangan dengan air mengalir atau cairan pembersih tangan serta desinfektan. Selain itu, untuk peserta didik disabilitas rungu harus disediakan masker tembus pandang. Waktu Kegiatan Belajar Mengajar $(\mathrm{KBM})$

a.Jarak di Kelas

Pendidikan dasar dan menengah haruslah jaga jarak minimal 1,5 meter dan maksimal 18 peserta didik per kelas. SLB, jaga jarak minimal 1,5 meter dan maksimal 5 peserta didik per kelas.
PAUD, jaga jarak minimal 1,5 meter dan maksimal 5 peserta didik per kelas.

b.Kantin

Boleh beroperasi dengan tetap menjaga_protokol kesehatan di sekolah.

c.Kegiatan Ekstrakurikuler dan Olahraga

Diperbolehkan, kecuali kegiatan dengan adanya penggunaan alat/fasilitas yang harus dipegang oleh banyak orang secara bergantian dalam waktu yang singkat dan/atau tidak memungkinkan penerapan jaga jarak minimal 1,5 meter, misalnya: basket dan voli.

d.Cek Suhu

Protokol kesehatan di sekolah yang kedua adalah cek suhu.Saat berada di sekolah, peserta didik dan tenaga pengajar diwajibkan menggunakan masker. Setiap orang yang memasuki sekolah juga akan dicek suhunya dengan menggunakan thermogun. Sesuai aturan protokol kesehatan, peserta didik dan tenaga pengajar wajib berada dalam kondisi 


\section{WAHANA DEDIKASI}

sehat.Orang dengan penyakit

komorbid tidak diperkenankan masuk sekolah.Dan tidak memiliki gejala Covid-19 termasuk pada orang yang serumah dengan warga satuan pendidikan.

Manajemen kecerdasan dan aktualisasi diri merupakan suatu kompetensi yang leh seorang individu dalam menghadapi masa pandemic seperti saat sekarang ini, baik baik seorang peserta didik, pendidik, pekerja kantoran dan lainnya. Hal ini dikarenakan dengan adanya kekampuan dalam mengatur diri sehingga dimasa pandemic ini seorang individu masih data berkarya denga berbagai maam protocol Kesehatan yang ketat.

Ulasan dan analisis situasi tentang pentingnya pemahaman atau studi interaktif tentang Manajemen kecerdasan dan aktualisasi diri dimasa new normal oleh peserta didik penting diberikan (Mukhayatun, Sugiyo, \& Tadjri.,2014), sehingga tujuan dari Pendidikan yaitu mengembangkan potensi peserta didik agar menjadi manusia yang beriman dan bertakwa kepada Tuhan Yang Maha Esa, berakhlak mulia, sehat, berilmu, cakap, kreatif, mandiri, dan menjadi warga negara yang baik dapat terwujud (Triyono et al, 2019)

\section{BAHAN DAN METODE}

Kegiatan pengabdian kepada masyarakat ini dilaksanakan pada hari Kamis, 8 Februari 2021 di SMA dan SMK DEK Padang melalui Google Meet. Pelaksanaan kegiatan pengabdian ini menggunakan metode ceramah, tanya jawab, diskusi (Anitah: 2014; Sugiyanto: 2009). Metode ceramah dilaksanakan pada awal kegiatan pengabdian yang mana pemateri menjelaskan materi tentang kolaborasi pendidik dan peserta didik dalam proses pembelajaran pada masa New Normal.

Metode tanya jawab dikalukan setelah pemateri memberikan ceramah (Pasaribu: 2005) kepada Guru di SMA dan SMK DEK Padang, hal ini dilakukan oleh pemateri. Sehingga Guru yang masih 


\section{WAHANA DEDIKASI}

ragu atau bingung dengan materi

yang sampaikan bisa bertanya secara

langsung kepada pemateri. Sementara

metode diskusi digunakan dalam

rangka memberikan kesempatan

kepada guru untuk mengungkapkan

pengalaman, pendapat dan bentuk

kolaborasi yang sudah dilakukan

selama proses pembelajaran pada

masa New Normal. Kegiatan

pengabdian ini dilaksanakan selama 1

bulan dengan rincian sebagai sebagai

berikut.

Tabel 1. Waktu Pelaksanaan

\begin{tabular}{|c|c|c|}
\hline Tanggal & $\begin{array}{l}\text { Pelaksana } \\
\text { /Pemateri }\end{array}$ & $\begin{array}{l}\text { Rincian } \\
\text { Kegiatan }\end{array}$ \\
\hline $\begin{array}{l}10 \\
\text { Desembe } \\
\text { r } 2020\end{array}$ & $\begin{array}{l}\text { Semua } \\
\text { TIM PKM }\end{array}$ & $\begin{array}{l}\text { Penempatan } \\
\text { tempat dan survei } \\
\text { awal untuk } \\
\text { kesedian menjadi } \\
\text { mitra pengabdian }\end{array}$ \\
\hline $\begin{array}{l}19 \\
\text { Desembe } \\
\text { r } 2020\end{array}$ & $\begin{array}{l}\text { Semua } \\
\text { TIM PKM }\end{array}$ & \begin{tabular}{lr}
\multicolumn{3}{l}{ Melakulkan } \\
diskusi dengan \\
Guru di & SMK \\
dan SMA & DEK \\
untuk & \\
mengetahui & \\
kebutuhan guru \\
di SMA & dan \\
SMK DX & \\
\end{tabular} \\
\hline $\begin{array}{l}25 \\
\text { Desembe } \\
\mathrm{r} \quad 2020- \\
20 \\
\text { Januari } \\
2021\end{array}$ & $\begin{array}{l}\text { Semua } \\
\text { TIM PKM }\end{array}$ & \begin{tabular}{l}
\multicolumn{2}{l}{ Perumusan } \\
Pelaksanaan \\
kegiatan PKM \\
oleh TIM dan \\
pengajuan \\
Proposal \\
UP3M ke
\end{tabular} \\
\hline $\begin{array}{l}28 \\
\text { Januari }\end{array}$ & $\begin{array}{l}\text { Semua } \\
\text { TIM }\end{array}$ & $\begin{array}{l}\text { Pelaksanaan } \\
\text { kegiatan }\end{array}$ \\
\hline
\end{tabular}

\begin{tabular}{|c|c|c|}
\hline 2021 & $\begin{array}{l}\text { PKM } \\
\text { Pemateri: } \\
\text { Dra. Hj. } \\
\text { Fitria } \\
\text { Kasih, } \\
\text { M.Pd., } \\
\text { Kons }\end{array}$ & $\begin{array}{l}\text { pengabdian di } \\
\text { SMA dan SMK } \\
\text { DEK Padang } \\
\text { dengan langkah- } \\
\text { langkah sebagai } \\
\text { berikut: } \\
\text { 1. Perkenalan } \\
\text { TIM PKM } \\
\text { 2. Sambutan } \\
\text { dari } \\
\text { Sekolah } \\
\text { Mitra PKM } \\
\text { 3. Pemberian } \\
\text { materi } \\
\text { PKM } \\
\text { 4. Dialog } \\
\text { interaktif } \\
\text { dengan } \\
\text { Guru } \\
\text { a. Peserta } \\
\text { PKM } \\
\text { bertany } \\
\text { a } \\
\text { b. Pemate } \\
\text { ri } \\
\text { manja } \\
\text { wab } \\
\text { permas } \\
\text { alahan } \\
\text { yang } \\
\text { dialami } \\
\text { peserta } \\
\text { PKM } \\
\text { 5. Penutup }\end{array}$ \\
\hline $\begin{array}{l}5 \\
\text { Februari } \\
2021\end{array}$ & $\begin{array}{l}\text { Semua } \\
\text { TIM PKM }\end{array}$ & Evaluasi kegiatan \\
\hline $\begin{array}{l}11 \\
\text { Februari } \\
2021\end{array}$ & $\begin{array}{l}\text { Semua } \\
\text { TIM PKM }\end{array}$ & $\begin{array}{l}\text { Pelaksanaan } \\
\text { tindak lanjut } \\
\text { berdasarkan hasil } \\
\text { evaluasi kegiatan }\end{array}$ \\
\hline
\end{tabular}

\section{HASIL DAN PEMBAHASAN}

Berdasarkan hasil evaluasi kegitan yang dilakukan dapat dikatakan bahwa kegiatan PKM berhasil dan berjalan dengan lancar. 


\section{W/AHANA DEDIKASI}

Keberhasilan PKM didasarkan pada indikator tingkat antusias Guru dalam mengikuti kegiatan dialog interaktif dari awal sampai akhir kegiatan. Berikut kegiatan yang dilakukan oleh tim PkM:

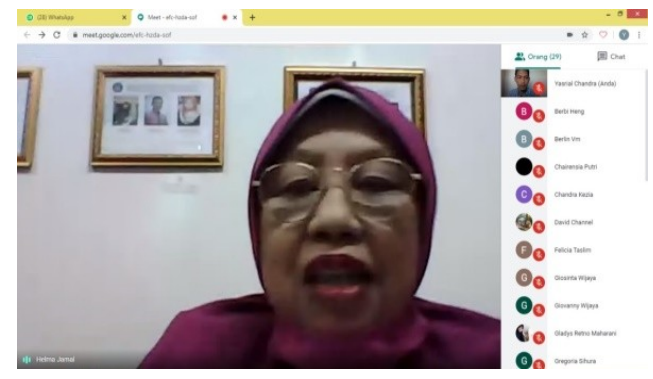

Gambar 1. Pemaparan Materi PkM

Selanjutnya dilihat dari keseriusan dalam mendengarkan materi yang disampaikan, serta partisipasi Guru dalam dialog interaktif. Kemudian pemateri juga memberikan nomor handphone agar bisa berdiskusi lebih lanjut diluar sesi pengabdian.

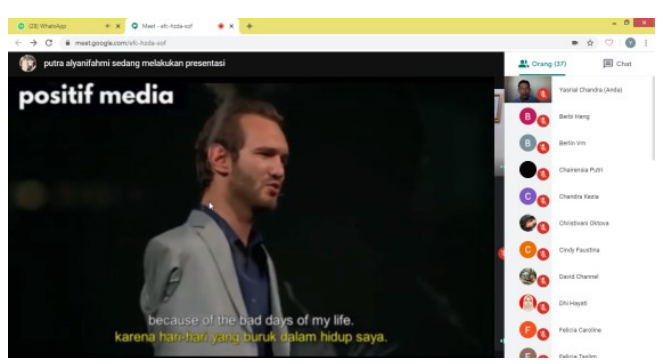

Gambar 2. Materi Audovisual yang ditampilkan
Kegiatan pengabdian masyarakat yang telah selsai dilakukan, maka demi perbaikan kegiatan ini selanjutnya dilakukan evaluasi terhadap kegiatan tersebut, dimana dengan menggunakan metode online mneggunakan media google form terungkap bahwa $88 \%$ menanggapi positif terhadap kegiatan yang dilakukan, seperti data gambar di bawah ini:

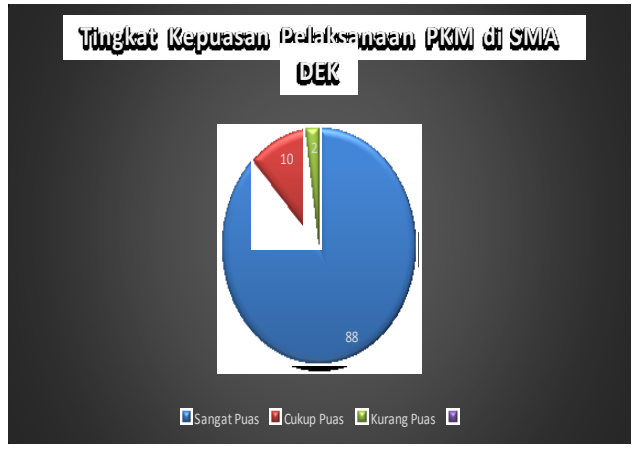

Gambar 3. Tingkat Kepuasan Siswa SMA DEK

Namun setelah tim evaluasi lebih seksama pencapaian ini belum menggembirakan

dikarenakan keterbatasan waktu kemudian proses yang dilakukan secara online. Selanjutnya informasi ini akan kami sampaikan dengan guru BK di SMK DEK dan pimpinan. Adapun kesepakatan pimpinan sekolah 


\section{WAHANA DEDIKASI}

dengan Pimpinan Program Studi pengaktualisasian diri dimasa new bahwa kegiatan selanjutnya berupa normal ini

dialog interaktif yang akan diberikan kepada Para pendidik di SMK DEK.

Penekanan dan pemasyarakatan tentang aturan dan protokol Kesehatan harus turut di galakkan oleh semua stake holder yang ada pada intitusi tertentu dan orang-orang yang memliki hubungan dengan para siswa atau remaja yang ada di SMK DEK.

Adanya kontrol dari stakeholder SMA DEK dan Tokoh Masyarakat maka diharapkan proses aktualisasi diri yang memang juga dibutuhkan oleh remaja selama masa pertumbuhan di kondisi pandemic ini tetap maksimal sehigga ketercapaiandan pemnuhan tugas remaja seca psikologis dapat tetap berjalan sebagaimana mestinya. Selanjutnya melalui kegiatan PKM yang dilakukan oleh Tim dosen Program Studi BK maka diberikanlah beberapa informasi dan pelatihan bagaimana mengembangkan cara management diri dalam

\section{KESIMPULAN \\ Pelaksanaan PKM tentang} kolaborasi pendidik dan peserta didik dalam proses pembelajaran pada masa new normal berjalan dengan lancar dan bisa dikatan berhasil. PKM ini bisa dijadikan suatu trobosan baru yang bisa dilakukan untuk menjawab berbagai permaslahan-permasalahan yang dialami oleh guru dan peserta didik pada masa new normal. Kolaborasi menjadi tren dunia pendidikan saat ini dan merupakan satu dari kecakapan abad 21 yang harus dimiliki pendidik dan peserta didik.

Bentuk kolaborasi yang harus terbaun antara pendidik dan peserta didik harus dilandasi oleh saling percaya, saling menghargai, saling menerima, saling peduli dan saing menguatkan untuk mencapai tujuan yang telah ditentukan. Upaya kolaborasi yang dilakukan guru dan peserta didik yaitu menerima dan menghargai perbedaan, menjalin 


\section{WAHANA DEDIKASI}

hubungan yang baik dengan semua, melakukan banyak hal secara berkelompok dan bersama, mampu berkontribusi dalam semua hal, mewujudkan rasa empati kepada semua, dan memiliki prinsip kesuksesan milik bersama dan nikmati bersama.

\section{UCAPAN TERIMAKASIH}

Selanjutnya saya ucapkan terimakasih kepada Kepla Sekolah, Guru, UP3M STKIP PGRI Sumatera Barat, TIM pelaksana Pengabdian, dan semua pihak yang sudah terlibat dalam pelaksanaan pengabdian kepada masyarakat sehingga kegiatan ini berhasil. Selanjutnya kepada jurnal penerbit yang sudah memberikan kesempatan untuk mempublikasikan PKM yang sudah dilaksanakan.

\section{DAFTAR PUSTAKA}

Goble, F. G. (1994). Mazhab Ketiga Psikologi Humanistik Abraham Maslow, Penerjemah Drs. $A$. Supratiknya (Yogyakarta: Kanisius, 1994).

Herts, K. L., Wallis, E., \& Maslow, G. (2014). College freshmen with chronic illness: A comparison with healthy firstyear students. Journal of College Student Development, 55(5), 475-480. McLeod, S. (2007). Maslow's hierarchy of needs. Simply psychology, 1, 1-8.

Mukhayatun, U., Sugiyo, S., \& Tadjri, I. (2014). Model Program Bimbingan Dan Konseling Komprehensif Sekolah Menengah Pertama (Studi Pada Smp Negeri 6 Rembang). Jurnal Bimbingan Konseling, 3(1).

Oktarosada, D. (2017). Implementasi pendidikan karakter pada pembelajaran pendidikan agama islam di kelas X: Studi kasus di SMK Muhammadiyah $2 \quad$ kalirejo (Doctoral dissertation, UIN Raden Intan Lampung).

Perbowosari, H. (2016). Peran Kecerdasan Emosional Dalam Pendidikan

Karakter. Prosiding Nasional. Susanto, H., \& Akmal, H. (2018). Efektivitas

Penggunaan Aplikasi Pembelajaran Berbasis Mobile Smartphone Sebagai Media Pengenalan Sejarah Lokal Masa Revolusi Fisik Di Kalimantan Selatan Pada Siswa Sekolah Menengah Atas. HISTORIA: 


\section{WAHANA DEDIKASI}

Jurnal Program Studi

Pendidikan Sejarah, 6(2), 197-206.

Syaharuddin, S. (2020). Menimbang

Peran Teknologi dan Guru

dalam Pembelajaran di Era

COVID-19. Menimbang

Peran Teknologi dan Guru

dalam Pembelajaran di Era

COVID-19.

Syaharuddin, S., Rahman, A. M., \&

Fitriyani, R. (2020).

Utilization Of Social

Community as Learning

Resources On Social Studies.

The Kalimantan Social

Studies Journal, 1 (1), 18-24.

Triana, L. (2011). Pola Penerapan

Pendidikan Karakter Siswa di

SMA Negeri 3 Pati (Doctoral

dissertation, Universitas

Negeri Semarang (UNNES)).

Triyono, T., Febriani, R. D., Hidayat, H., \& Putri, B. N. D. (2019).

Pelatihan Penggunaan

Teknologi Informasi Kepada

Guru Bimbingan Dan

Konseling. WAHANA

DEDIKASI, 2(1). 